\title{
Prediction of Rice Yield and Economic Thresholds by Some Weeds-Rice Competition in Transplanted Rice Cultivation
}

\author{
Byeong-Chul Moon ${ }^{1 *}$, Jong-Gun Won ${ }^{2}$, Young-Lim Kim ${ }^{1}$, Sung-Woo Kim ${ }^{1}$ \\ In-Yong Lee ${ }^{1}$, Jae-Eup Park ${ }^{1}$ and Do-Soon Kim ${ }^{3}$

\section{벼 기계이앙 재배에서 벼와 잡초 경합에 따른 벼 수량 및 요방제수준 예측}

문병철 $^{1 *}$, 원종건 ${ }^{2}$, 김영림 ${ }^{1}$, 김성우 ${ }^{1}$, 이인용 ${ }^{1}$, 박재읍 $^{1}$, 김도순 ${ }^{3}$

\begin{abstract}
Field experiments were conducted to predict rice yield losses caused by Echinochloa crus-galli (L.)P. Beauv., Bidens frondosa L. and Aeschynomeme indica L. at a range of plant densities under machine transplanted rice cultivation in different regions of Korea in 2006, and to determine their economic threshold levels (ET). All data were fitted to Cousens' rectangular hyperbola to estimate parameters for predicting rice yield loss. The rice yield loss models of Bidens frondosa L. was predicted as $\mathrm{y}=5.43 /(1+0.0113 \mathrm{x}), \mathrm{R}^{2}=0.963$, A. indica was $\mathrm{y}=5.47 /(1+0.0332 \mathrm{x}), \mathrm{R}^{2}=0.976$ and E. crus-galli $\mathrm{y}=$ $5.43 /(1+0.01552 \mathrm{x}), \mathrm{R}^{2}=0.950$. The mean competitivities represented by the parameter, whose reciprocal ( $1 /$ $\beta$ ) is a weed density reducing crop yield by $50 \%$. Those of E. crus-galli, B. frondosa and A. indica were $0.01552,0.01113$ and 0.0332 in normal-season machine transplanting of Korea, respectively. Single year mean economic thresholds (ET) of $A$. indica were $0.5,0.6$ and 0.7 plant $\mathrm{m}^{-2}$ with the application of flucetosulfuron, flucetosulfuron+imazosulfuron GR and flucetosulfuron+imazosulfuron+carfentrazone GR herbicides, respectively. Meanwhile ET values of 1.6, 1.9 and 1.9 plants $\mathrm{m}^{-2}$ for $B$. frondosa, 1.2, 1.4, and 1.4 plants $\mathrm{m}^{-2}$ for E. crus-galli.
\end{abstract}

Key words: economic threshold; interference; weed density.

\footnotetext{
${ }^{1}$ National Academy of Agricultural Science, RDA, Suwon 441-707, Korea(농촌진흥청 국립농업과학원, 441-707 경기도 수원시 권선 구 수인로 150번지).

${ }^{2}$ Gyeongbuk Agricultural Research and Extension Services, Yeongyang 764-803, Korea(경북농업기술원 영양고추시험장, 764-803 경북 영양군 영양읍 대천리 579-3).

${ }^{3}$ Seoul National University, Seoul 151-921, Korea(서울대학교 농업생명과학대학, 151-921 서울시 관악구 관악로 599).

* 연락저자(Corresponding author) : Phone) +82-31-290-0581, Fax)+82-31-290-0508, E-mail) moonbc@korea.kr
} 


\section{INTRODUCTION}

Since uncontrolled weeds can lead to rice yield losses as high as $80 \%$ (Smith 1983), weed control is an essential and intensive component of rice production. Accurate prediction of weed-crop interactions is required for integrated weed management (Swanton and Murphy 1996). Mathematical models that summarize the quantitative knowledge of the impact of weed competition on crop yield can provide useful information to support weed management decisions (Vandevender et al. 1997). Much effort has been made to develop such mathematical weed-crop interference models (Cousens 1985; Kropff and Spitters 1991), which are commonly used to quantify competitive relationships and predict yield loss. Among those models, the rectangular hyperbola based on weed density (Cousens 1985) has been most widely used to predict crop yield losses as a function of weed density in various crops, such as wheat (Kim et al. 2002), soybean (Cowan et al. 1998) and maize (Lindquist et al. 1996). Little effort has been made to investigate relationships of rice-weed competition, although Lindquist and Kropff (1996) introduced an ecophysiological model for irrigated rice-Echinochloa competition. Recently Ni et al. (2004) analyzed competition between wet-seeded rice and $E$. crus-galli using a response-surface model based on the rectangular hyperbola.

No study has been conducted to investigate the competition relationship between rice and paddy weeds. As some paddy weeds including E. crus-galli are very important in rice production, particularly in Korea and Japan, mathematical quantification and prediction of their competition impacts on rice are required for efficient weed control decision-making, from both economical and environmental viewpoints. Therefore, this study was conducted to investigate the competition relationships of E. crus-galli, B. frondosa, and $A$. indica with transplanted rice. The aims of the study were to (a) predict crop yield as a function of weed density using the rectangular hyperbola as a prediction model, and (b) determine the economic threshold levels for E. crus-galli, B. frondosa, and A. indica in a transplanted rice cropping system.

\section{MATERIALS AND METHODS}

Field experiments were conducted to evaluate competition effects of $E$. crus-galli, A. indica and $B$. frondosa on transplanted rice in major rice cropping regions in Korea. Experiments with E. crus-galli, A. indica and $B$. frondosa were conducted in Daegu and Suwon in 2006. The experiments consisted of three replicates of a completely randomized block design. The plot size was $2 \times 2 \mathrm{~m}$. Thirty-day-old-seedlings of rice (Oryza sativa cv. Ilmibyeo) were transplanted at a density of 23.8 hills $\mathrm{m}^{-2}\left(14 \times 30 \mathrm{~cm}^{2}\right.$ space $)$ equivalent to about 72 rice seedlings $\mathrm{m}^{-2}$ on 25 May in 2004. The densities of $E$. crus-galli and A. indica were $0,1,8$, 24, 48 and 96 plants $\mathrm{m}^{-2}$. The densities of B. frondosa were $0,1,8,48,96$ and 192 plants $\mathrm{m}^{-2}$. The plant densities were artificially adjusted by sowing seeds of E. crus-galli, A. indica and B. frondosa, with handweeding to remove naturally occurred background weeds.

Fertilizer was applied as a basal release with $\mathrm{N}$, of 55,67 , and $225 \mathrm{~kg} \mathrm{ha}^{-1}$ respectively before harrowing, followed by top-dressing of $22 \mathrm{~kg} \mathrm{ha}^{-1}$ of $\mathrm{N}$ at the tillering stage of the rice, 10 days after transplanting (DAT), and 33 and $29 \mathrm{~kg} \mathrm{ha}^{-1}$ of $\mathrm{N}$ and $\mathrm{K}_{2} \mathrm{O}$ at the panicle initiation stage of the rice. To investigate competition between rice and the weeds, rice was sampled from an area of $1.0 \mathrm{~m}^{2}$ and grain yield measured after polishing.

Rice grain yields were fitted to the following equation 1, rectangular hyperbola (Cousens 1985), to estimate parameters for predicting yields as a function of weed density.

$$
Y=\frac{Y_{0}}{1+\beta X}
$$

where $Y_{0}$ is weed-free rice yield $\left(t h^{-1}\right), \beta$ is a 
measure of weed competitivity (a weed density of $1 / \beta$ reduces the rice yield by $50 \%$ ) and $\mathrm{X}$ is weed density.

Economic thresholds (ET) of E. crus-galli, A. indica and $B$. frondosa were estimated by equating the cost of controlling these weeds with the value of rice yield gained by herbicide application. Their calculation was based on the equation developed by Cousens (1987) as follows :

$$
E T=\left(C_{h}+C_{a}\right) /\left(Y_{o} P L H \quad\right)
$$

where $C_{h}$ is herbicide cost (US\$ ha ${ }^{-1}$ ), $C_{a}$ is application cost (US\$ ha $\left.{ }^{-1}\right), Y_{o}$ is weed free rice yield $\left(\mathrm{t} \mathrm{ha}{ }^{-1}\right), \mathrm{P}$ is value per unit of crop (US $\$ \mathrm{t}^{-1}$ ), $\mathrm{L}$ is proportional loss per unit weed density, and $\mathrm{H}$ is herbicide efficacy, a proportional reduction in weed density or weed biomass by the herbicide treatment. All statistical analyses were conducted using Genstat (Genstat Committee, 2002).

\section{RESULTS AND DISCUSSION}

By fitting the rectangular hyperbola (equation 1) to rice yield, weed-free rice yield $\left(\mathrm{Y}_{\mathrm{o}}\right)$ and weed competitivity $(\beta)$ of the three weeds were estimated. In competition with E. crus-gall, the estimated weed-free yield were $5.42 \mathrm{t} \mathrm{ha}^{-1}$ (Fig. 1) and those of competition with $A$. indica and $B$. frondosa was 5.47 and $5.43 \mathrm{t}$ $\mathrm{ha}^{-1}$, respectively. The competitiveness represented by the parameter, whose reciprocal $(1 / \beta)$ is the weed density that reduces crop yield by $50 \%$. Those of $E$. crus-galli, B. frondosa and A. indica were 0.01552, 0.0113 and 0.0332 , respectively for normal-season machine transplanting in Korea. Based on parameter estimates and equation 1, rice yield as a function of $E$. crus-galli competition was calculated (Fig. 1). There is good agreement between calculated and observed yield as E. crus-galli density increases, showing that competition between rice and E. crus-galli was described well by the hyperbolic model. Fit of the model was also good for rice in competition with $B$. frondosa and $A$. indica.

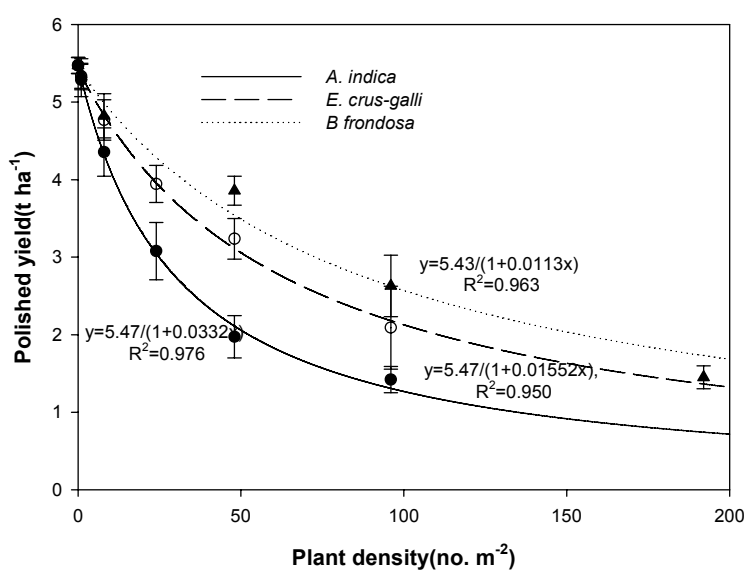

Fig. 1. Observed and predicted rice yield as a function by densities of $A$. indica, E. crus-galli, and B. frondosa in Suwon and Daegu, Korea. The predicted rice grain yield (continuous line) was calculated using equation 1.

The relationship between rice yield and the other weed density was well explained by the rectangular hyperbola. Overall, the estimated weed competitivities of other weed species in transplanted rice cultivation revealed that $A$. indica showed the greatest competitivity (0.0332) followed by E.crus-galli and $B$. frondosa. The results of the competitivity obtained through this experiment clearly demonstrated the differences in rice sensitivity to the presence of the main paddy weeds. It likewise showed that the amount of rice yield reduction depends on weed species densities. A. indica was widely distributed on soils with texture ranging from sandy loam to clay and it can be a serious weed in rice paddies (Kretschmer \& Bullock 1980). This weed grow very fast when temperatures are high during the middle growth stage of rice, reaching great heights at the late growth stage of rice that could even block the incoming light from penetrating into the rice crop hence considerably reducing its expected yield.

Single year economic thresholds of E. crus-galli, $B$. frondosa and $A$. indica were calculated by using eqn 2 and the parameter estimates in Table 1 . The herbicide price to control weeds including the application cost was estimated to be 97.3 to 123.0 US $\$ \mathrm{ha}^{-1}$. The price 
Table 1. Parameter estimates and economic threshold (ET) of weeds in machine transplanted rice cultivation.

\begin{tabular}{|c|c|c|c|c|c|c|c|c|c|c|c|}
\hline \multirow{2}{*}{$\begin{array}{c}\text { Weed } \\
\text { species }\end{array}$} & \multicolumn{3}{|c|}{$\mathrm{C}_{\mathrm{a}}\left(\$ \mathrm{ha}^{-1}\right)^{1)}$} & \multirow{2}{*}{$\begin{array}{c}\mathrm{C}_{\mathrm{h}}^{3)} \\
\left(\$ \mathrm{ha}^{-1}\right)\end{array}$} & \multirow{2}{*}{$\begin{array}{c}\mathrm{Y}_{\mathrm{o}}^{4)} \\
\left(\mathrm{t} \mathrm{ha}^{-1}\right)\end{array}$} & \multirow{2}{*}{$\begin{array}{c}P^{5)} \\
\left(\$ t^{-1}\right)\end{array}$} & \multirow{2}{*}{$L^{6)}$} & \multirow{2}{*}{$\mathrm{H}^{7)}$} & \multicolumn{3}{|c|}{$\mathrm{Et}\left(\mathrm{No} \mathrm{m}^{-2}\right)$} \\
\hline & $A^{2)}$ & B & $\mathrm{C}$ & & & & & & A & $\mathrm{B}$ & $\mathrm{C}$ \\
\hline A. indica & 97.3 & 119.5 & 123.0 & 27.1 & 5.5 & 1442.5 & 0.032 & 0.9 & 0.5 & 0.6 & 0.7 \\
\hline B. frondosa & 97.3 & 119.5 & 123.0 & 27.1 & 5.4 & 1442.5 & 0.011 & 0.9 & 1.6 & 1.9 & 1.9 \\
\hline E. crus-galli & 97.3 & 119.5 & 123.0 & 27.1 & 5.5 & 1442.5 & 0.015 & 0.9 & 1.2 & 1.4 & 1.4 \\
\hline
\end{tabular}

${ }^{1)} \mathrm{C}_{\mathrm{a}}$, application cost; ${ }^{2)} \mathrm{A}$-flucetosulfuron GR, B-flucetosulfuron+imazosulfuron GR, C-flucetosulfuron+imazosulfuron+ carfentrazoneethyl for weeds; ${ }^{3)} \mathrm{C}_{\mathrm{h}}$, herbicide cost; ${ }^{4)} \mathrm{Y}_{\mathrm{o}}$, weed free crop yield; ${ }^{5)} \mathrm{P}$, value per unit of crop; ${ }^{6} \mathrm{~L}$, proportion of yield loss per unit weed density; ${ }^{7} \mathrm{H}$, herbicide efficacy calculated as efficacy/100.

of grain rice was 1442.5 US $\$ \mathrm{t}^{-1}$ in 2010. Herbicide efficacy was assumed to be 0.90 regardless of year and herbicide.

The estimated economic thresholds (ET) of $A$. indica were $0.5,0.6$ and 0.7 plant $\mathrm{m}^{-2}$ with the application of flucetosulfuron, flucetosulfuron+imazosulfuron GR and flucetosulfuron+imazosulfuron+carfentrazone GR herbicides, respectively. Meanwhile those of $B$. frondosa were 1.6, 1.9 and 1.9 plants $\mathrm{m}^{-2}$ and $1.2,1.4$, and 1.4 plants $\mathrm{m}^{-2}$ for E. crus-galli.

The study had clearly demonstrated that the rectangular hyperbolic model effectively described the competition relationships between the weeds and rice, successfully predicted rice yields as a function of weed density and had estimated ET values. Therefore, these results can be used to support decision-making on herbicide application in machine transplanted rice cultivation. However, it has still some limitations in regard to the required herbicide dose in practical fields infested with multiple weed species.

\section{요 약}

본 연구는 벼에 대한 피, 자귀풀과 미국가막사리의 경합에 따른 수량피해 예측과 경제적인 잡초관리를 위 한 방제필요 밀도를 구명하고자 하였다. 수원과 대구 지역에서 얻어진 성적을 종합한 예측모델식에 따르면 논에서 피, 자귀풀, 미국가막사리가 완전히 방제되었 을 때의 쌀수량은 각각 $5.5 \mathrm{t}, 5.5 \mathrm{t}, 5.4 \mathrm{t}$ 으로 예측되었
다. 초종별 평방미터당 요방제 필요밀도는 자귀풀은 제초제 종류별로 $0.5 \sim 0.7$ 본, 피는 $1.2 \sim 1.4$ 본, 미국가 막사리는 $1.6 \sim 1.9$ 본인 것으로 예측되었다.

\section{ACKNOWLEDGEMENTS}

This study was carried out with the support of "Research Program for Agricultural Science \& Technology Development (Project No. 006340201)", National Academy of Agricultural Science, Rural Development Administration, Republic of Korea.

\section{REFERENCES}

Cusens, R. 1985. A simple model relating yield loss to weed density. Annals of Applied Biology 107: 239-252.

Cousens, R. 1987. Theory and reality of weed control thresholds. Plant Prot. Q.2:13-20.

Cowan, P., S. E. Weaver, and C. J. Swanton. 1998. Interference between pigweed (Amaranthus spp.), barnyardgrass (Echinochloa crus-galli), and soybean (Glycine max). Weed Sci. 46:533-539.

Kim, D. S., P. Brain, E. J. P. Marshall and J. C. Caseley. 2002. Modelling herbicide dose and weed density effects on crop-weed competition. Weed Research 42:1-13.

Kretschmer, A. E. and R. C. Bullock. 1980. Aeschynomene 
spp. : Distribution and potential use. Proceedings of the Soil and Crop Science Society of Florida 39:145-152.

Kropff, M. J. and C. J. T. Spitters. 1991. A simple model of crop loss by weed competition from early observations on relative leaf area of weeds. Weed Research 31:97-105.

Lindquist, J. L., D. A. Mortensen, S. A. Clay, R. Schmenk, J. J. Kells, K. Howatt and P. Westra. 1996. Stability of corn (Zea mays)-velvetleaf (Abutilon theophrasti) interference relationships. Weed Sci. 44:309-313.

Ni, H., M. Keith and P. R. Restituta. 2004. Analysis of competition between wet-seeded rice and barnyard grass (Echinochloa crus-galli) using a responsesurface model. Weed Sci. 52:142-146.

Smith, R. J. 1983. Weeds of major economic importance in rice and yield losses due to weed competition. In : Proceedings of the Conference on Weed Control in Rice, IRRI, LosBanos, Philippines, 19-36.

Swaton, C. J. and S. D. Murphy. 1996. Weed science beyond the weeds : the role of integrated weed management (IWM) in agroecosystem health. Weed Sci. 44:437-445.

Vandevender, K. W., T. A. Costello and R. J. Smith. 1997. Model of rice (Oryza sativa) yield reduction as a function of weed interference. Weed Sci. 42:218-224. 